\title{
Chemical characterization and radical scavenging activity of leaves of Juniperus foetidisima, J. excelsa and J. communis from Macedonian flora
}

\author{
Marija Karapandzova $^{1 *}$, Gjose Stefkov ${ }^{1}$, Ivana Cvetkovikj ${ }^{1}$, Floresha Sela ${ }^{1}$, \\ Tatjana Kadifkova Panovska ${ }^{2}$, Svetlana Kulevanova ${ }^{1}$ \\ ${ }^{1}$ Institute of Pharmacognosy, Faculty of Pharmacy, University”Ss. Cyril and Methodius", Majka Tereza str. 47, \\ 1000 Skopje, R. Macedonia \\ 2Institute of Applied Biochemistry, Faculty of Pharmacy, University"Ss. Cyril and Methodius", Majka Tereza str. 47, \\ 1000 Skopje, R. Macedonia
}

Received: October 2014; Accepted: December 2014

\begin{abstract}
Chemical characterization of three Juniperus species: J. foetidisima (JF), J. excelsa (JE) and J. communis (JC) from Macedonian flora enclosed determination of yield and essential oil composition of the oils obtained by hydro-distillation of dried leaves and determination of the content of total phenols and total flavonoids in dried plant material. GC/FID/MS analysis showed mainly monoterpene profile of the JC oil and combined monoterpene/sesquiterpene profile of JF and JE oils. Sesquiterpene cedrol was found as an important constituent of the $\mathrm{JF}$ and JE, thus the JF oil was characterized by three main components ( $\alpha$-pinene, limonene and cedrol, in amount up to 67.63\%, 27.11\% and $33.91 \%$, respectively) and JE oil by four components ( $\alpha$-pinene, sabinene, cis-thujone and cedrol, in amount up to $33.83 \%, 29.49 \%$, $26.20 \%$ and $24.44 \%$, respectively). The JC oil was free of cedrol, but contained relatively large sesquiterpene fraction (sesquiterpene hydrocarbons and oxygen containing sesquiterpenes in amounts up to $28.64 \%$ and $13.57 \%$, respectively). The JC oil was characterized by three monoterpene components ( $\alpha$-pinene, sabinene and terpinen-4-ol, presented up to $28.68 \%, 16.27 \%$ and $12.16 \%$, respectively). The content of total phenols determined by Folin-Ciocalteu method ranged from 96.18-122.91 mg GAE/g dw (water extraction) while the content of total flavonoids ranged from $2.05-11.91 \mathrm{mg} \mathrm{CE} / \mathrm{g} \mathrm{dw}$ (ethanol extraction). Both water and ethanol extracts possessed radical scavenging activity against DPPH radical. Water extracts were more powerful with $\%$ of inhibition of DPPH ranging up to $64.52 \%, 67.40 \%$ and $78.23 \%$ for water extract $(10 \mathrm{mg} / \mathrm{ml})$ of JF, JE and JC, respectively. Obtained results showed correlation with the content of total phenols.
\end{abstract}

Keywords: Juniperus communis, Juniperus excelsa, Juniperus foetidisima, essential oil composition, GC/MS, total phenols, total flavonoids, DPPH.

\section{Introduction}

Juniperus is one of the major genera of Cupressaceae family consisting of approximately 70 species variable in size and shape, from tall trees to columnar or low spreading

\footnotetext{
*Marija_Karapandzova@ff.ukim.edu.mk;
} marijakarapandzova@yahoo.com shrubs. The plants are evergreen with leave-like or scalelike leaves. Many of Juniperus species are known and used as medicinal or commercially valuable plants. The common juniper, Juniperus communis L. (Cupressaceae), is an evergreen shrub or small coniferous tree, wide spread through the cool temperate Northern Hemisphere. Juniperus excelsa Bieb. is a large shrub or tree, spread mainly 
throughout the eastern Mediterranean starting from northeastern Greece and southern Bulgaria across Turkey to the Middle-East countries (Syria and Lebanon) and the Caucasus Mtn. It occurs in Iran, Pakistan and Oman as well (Khan et al., 2012). Juniperus foetidissima Willd. is a medium-size tree, spread mainly throughout the southeastern Europe and southwestern Asia, starting from southeastern Albania and northern Greece, across Turkey, Syria and Lebanon to the northern Iran and southwestern Turkmenistan. It often occurs together with J. excelsa Bieb., but it could be distinguished by its thicker shoots and green leaves (Marcysiak et al., 2007).

The above-ground parts, especially leaves and berries of Juniperus species are rich in essential oil that has characteristic aromatic flavour and bitter taste. Due to its diuretic and gastrointestinal properties, common juniper ( $J$. communis) is used as medicinal plant for centuries. Besides berry essential oil, other juniper essential oil can be obtained from leaves, wood and seeds of the plant, usually by hydrodistillation (Orav et al., 2010a; Chatzopoulou and Katsiotis, 1993; Kumar et al., 2007). The oils are used in the pharmaceutical and cosmetic industries, for food and beverages, as well as for the production of perfumes. J. excelsa is a medicinal plant that has been used in folk medicine to treat dysmenorrhe, cough, bronchitis and colds, jaundice and tuberculosis and to induce menses and expel fetus (Emami et al., 2011). It is known as a remedy for diarrhea, abdominal spasm, asthma, fever, gonorrhea, headache and leucorrhoea (Khan et al., 2012). Among limited biological and pharmacological properties studied in vitro such as cytotoxic (Topcu et al., 2005) and antispasmodic activity (Atas et al., 2012), the most investigated were the antioxidant (Atas et al., 2012; Emami et al., 2007; Moein et al., 2010; Emami et al., 2011a) and antimicrobial activity (Ehsani et al., 2012; Atas et al., 2012; Asili et al., 2008; Unlu et al., 2008). However, there are few investigations regarding the biological activities of $J$. foetidissima also, with reports on antifungal (Balaban et al., 2007), antimicrobial (Asili et al., 2010), cytotoxic (Sadaeghi-Aliabdi et al., 2009), anticholinesterase (Ozturk et al., 2010), fumigant (Tayoub et al., 2012), anti-inflamatory (Orhan et al., 2012; Lesjak et al., 2013) and antioxidant effects (Lesjak et al., 2013; Emami et al., 2007; Emami et al., 2011b). These activities are probably result to the complex chemical pattern of terpene and other components.

There is a lot of literature data concerning the chemical composition of different Juniperus species, predominantly reporting the essential oil composition of berries and leaves. Thus, for $J$. communis considerable variations in the leaf oil composition were observed depending on the plant origin, however the essential oils is characterized with- $\alpha$-pinene, sabinene and myrcene, followed by trans-(E)-caryophyllene, muurolene, germacrene D and $\mathrm{B}$ and humulene (Orav et al., 2010a; Chatzopoulou and Katsiotis, 1993; Kumar et al., 2003, Ottavioli et al., 2009; Filipowicz et al., 2009; Shahmir et al., 2003; Orav et al., 2010b). The major oxygen containing terpenoids were terpinen-4-ol (Chatzopoulou and Katsiotis, 1993), rarely citronellol (Koukos and Papadopoulou, 1997) and terpenyl acetate (Angioni et al., 2003). The $J$. excelsa leaf essential oil is reach in cedrol, $\alpha$-pinene and limonene (Adams, 1990a), rarely $\alpha$-pinene (Topcu et al., 2005; Emami et al., 2010b) or cedrol (Topcu et al., 2005; Emami et al., 2010b). $J$. foetidissima contain essential oil in almost all parts of the plant, with variable composition. Sabinene, $\alpha$-thujone, terpinen-4-ol and $\gamma$-terpinene have been reported as major components of the leaf essential oil of $J$. foetidissima from Greece (Adams, 1987; Adams, 1990b). The monoterpenes sabinene, $\alpha$-pinene and limonene were predominant components of the essential oils of fruits and leaves of male and female plant of $J$. foetidissima from Iran (Asili et al., 2010). Turhish $J$. foetidissima contained $\beta$-thujone and cedrol as major components of the leaf essential oil, while sabinene was predominant component in the berry oil (Tunalier et al., 2002).

On the other hand, there is lack of information for the chemical composition and content of other secondary metabolites derived from the leaves of Juniperus species. Modnicki and Labedzka (2009) reported 2.40-3.43\% of total phenol contents (TPC) estimated as pyrogallol in leaves of J. communis. Aditionally, Moein at al. (2014) found a relationship between antioxidant potentials and phenolic compounds in fruits of $J$. excelsa, pointing out that most active fraction posses the highest reducing power $\left(\mathrm{IC}_{50} 61.4\right.$ $\mu \mathrm{g} / \mathrm{ml})$ and highest phenolic content $(82.9 \mathrm{mg} / \mathrm{g}$ ) (Moein et al., 2014). Further, the leave extracts of some other Juniperus species such as $J$. oxycedrus exhibited very high contents of polyphenols (133.08 $\mathrm{mgGAE} / \mathrm{g} \mathrm{dw}$ ) and flavonoids (61.52 mg CE/g dw) (Chaouche et al., 2014).

Juniperus species occur in Macedonian flora as an important floristic elements. J. communis is widely spread shrub throughout the whole territory of Republic of Macedonia (RM) (Micevski, 1998). The berries of this plant are extensively utilized in production of blended teas and other herbal medicinal products, in food industry and as a spice in production of alcoholic beverages. For years, the juniper berries and the juniper essential oil are exported from RM. Additionally, the juniper leaves are used in folk medicine for various purposes. J. excelsa medicinal properties are also known by people of RM as pain reliever, for curing cold, asthma, edema or skin diseases. J. foetidissima grows in southern parts of the country, but could be found in the valleys of the River Crn Drim and the River Treska in western and Karadzica Mtn. in central RM (Micevski, 1998). Shoots decoction of the plant is known in folk medicine for curing coughs and common cold. Up to now the chemistry of the leaves of these three Juniperus species from Macedonian flora is scientifically unknown and only one report on chemical composition, antioxidant and anti-inflammatory effects of Macedonian J. foetidissi$m a$ was published (Lesjak et al., 2013). Therefore the aim of the present study was chemical characterization of the 
leaves as well as assessment of radical scavenging activity of leaves extracts from J. communis, J. excesla and $J$. foetidissima from RM.

\section{Material and methods}

\section{Plant material}

Plant samples were collected in late autumn in 2010 and 2011. The terminal twigs of $J$. communis (JC) were collected from tree different localities in RM (Shara Mtn., Galicica Mtn. and Bistra Mtn.) (6 samples), terminal twigs with leaves of $J$. excelsa (JE) from two different localities (Velestovo and Dojran) (4 samples) and terminal plant twigs of $J$. foetidissima (JF) from four different localities in RM (Valandovo, Udovo, Veles and Velestovo) (8 samples). After air-drying in shadow the leaves were separated from stems, packed in paper bags and kept at dark and cool place until analysis.

\section{Chemicals}

All chemicals were purchased from Sigma-Aldrich (Missouri, USA), Merck (Darmstadt, Germany) and Alkaloid (Skopje, R. Macedonia).

\section{Essential oil isolation}

Essential oil isolation from plant leaves was made by steam distillation in special all-glass Clevenger type apparatus. For that purpose, $50 \mathrm{~g}$ of minced and dried leaves was distilled for 4 hours. After isolation, anhydrous sodium sulfate was added to remove residual water from the oil. Essential oil yield was expressed as \%, calculated on dried weight $(\mathrm{dw})$.

\section{Extraction procedure}

In order to determine the content of total flavonoids and total phenolic compounds, samples containing $1.0 \mathrm{~g}$ of powder dried plant material were processed. Two types of extracts were prepared, with $96 \%$ ethanol and water. The extraction procedure for sample preparation was performed with $10 \mathrm{ml}$ of extractive solvent for $30 \mathrm{~min}$ in ultrasonic bath $(50 / 60 \mathrm{~Hz}, 720 \mathrm{~W})$. The extracts were filtered and the volume was made up to $10 \mathrm{ml}$. The obtained ethanol and water extracts were used for evaluation of radical scavenging activity as well.

\section{GC/FID/MS analysis of essential oil}

Essential oil samples were analyzed on Agilent 7890A Gas Chromatography system equipped with FID detector and Agilent 5975C Mass Quadrupole detector as well as capillary flow technology which enables simultaneous analysis of the samples on both detectors. For that purpose,
HP-5ms capillary column (30 m x $0.25 \mathrm{~mm}$, film thickness $0.25 \mu \mathrm{m})$ was used. Operating conditions were as follows: oven temperature at $60{ }^{\circ} \mathrm{C}(5 \mathrm{~min}), 1{ }^{\circ} \mathrm{C} / \mathrm{min}$ to $80{ }^{\circ} \mathrm{C}(2$ $\mathrm{min}$ ) and $5{ }^{\circ} \mathrm{C} / \mathrm{min}$ to $280^{\circ} \mathrm{C}(5 \mathrm{~min})$; helium as carrier gas at a flow rate of $1 \mathrm{ml} / \mathrm{min}$; injector temperature $260{ }^{\circ} \mathrm{C}$ and that of the FID $270{ }^{\circ} \mathrm{C}$. $1 \mu \mathrm{l}$ of each sample was injected at split ratio 1:1. The mass spectrometry conditions were: ionization voltage $70 \mathrm{eV}$, ion source temperature $230{ }^{\circ} \mathrm{C}$, transfer line temperature $280{ }^{\circ} \mathrm{C}$ and mass range from $50-500$ Da. The MS was operated in scan mode. For GC/FID/MS analysis, the essential oil was dissolved in xylene to obtain $1 \mu \mathrm{l} / \mathrm{ml}$ oil solution.

Identification of the components present in essential oils was made by comparing mass spectra of components in essential oils with those from Nist, Wiley and Adams mass spectra libraries, by AMDIS (Automated Mass Spectral Deconvolution and Identification System) and by comparing literature and estimated Kovat's (retention) indices that were determined using mixture of homologous series of normal alkanes from $\mathrm{C}_{9}$ to $\mathrm{C}_{25}$ in hexane, under the same above mentioned conditions.

The percentage ratio of essential oils components was computed by the normalization method of the GC/FID peak areas without any correction factors.

\section{Determination of total phenolic content}

The total phenolic content (TPC) of the leaves was determined with the Folin-Ciocalteu reagent according to a procedure described by Singleton et al. (1999) with slight modifications. To $1.0 \mathrm{ml}$ of test sample (leaves extract), 0.5 $\mathrm{ml}(1: 10 \mathrm{v} / \mathrm{v}$ diluted with distilled water) Folin-Ciocalteau reagent was added and stirred for $5 \mathrm{~min}$ at room temperature. After $5 \mathrm{~min}, 0.4 \mathrm{ml}$ of $7.5 \%$ of sodium carbonate was added and made up to $10 \mathrm{ml}$ with distilled water. These mixtures were incubated at room temperature in the dark for 2 hours. After incubation, absorbance of blue color was measured at $765 \mathrm{~nm}$ using a UV-Vis spectrophotometer (Agilent 8453 UV-Vis spectrophotometer, Agilent Technologies, USA). The total phenolic content was determined as $\mathrm{mg}$ of gallic acid equivalents per gram of dried weight of plant material (mg GAE/g dw) using an equation obtained from standard gallic acid calibration graph.

\section{Determination of total flavonoid content}

The total flavonoid content (TFC) was determined using the aluminum chloride assay described by Talari et al. (2012) with slight modification. To an aliquot of the test sample ( $1.0 \mathrm{ml}$ of extract), $4.0 \mathrm{ml}$ of distilled water and 0.3 $\mathrm{ml}$ of $5.0 \%$ sodium nitrite were added and allowed to stand for $5 \mathrm{~min}$. Later, $0.3 \mathrm{ml}$ of $10.0 \%$ aluminum chloride was added and the mixture was incubated for $6 \mathrm{~min}$. $2.0 \mathrm{ml}$ of 1 $\mathrm{M}$ sodium hydroxide was added and the volume was made up to $10.0 \mathrm{ml}$ with distilled water. After incubation of 15 min, the mixture turned to pink and the absorbance was 
measured at $510 \mathrm{~nm}$ using a UV-Vis spectrophotometer (Agilent 8453 UV-Vis spectrophotometer, Agilent Technologies, USA). The TFC was expressed in $\mathrm{mg}$ of catechin equivalents per gram of dried weight of plant material ( $\mathrm{mg} \mathrm{CE} / \mathrm{g} \mathrm{dw})$ using an equation obtained from standard (+)-catechin calibration graph.

\section{Free radical scavenging activity - DPPH assay}

The scavenging activity of DPPH free radical of leaves extracts was done according to the method reported by Gyamfi et al. (1999) with minor modifications. $200 \mu \mathrm{l}$ of different concentrations of tested samples $(100,50,20$ and $10 \mathrm{mg} / \mathrm{ml}$ for ethanol extracts and $10,5,2$ and $1 \mathrm{mg} / \mathrm{ml}$ for water extracts) were placed in a cuvette and $4 \mathrm{ml}$ of $100 \mu \mathrm{m}$ methanolic solution of DPPH was added. Mixtures were shaken vigorously for $1 \mathrm{~min}$ and left to stand $10 \mathrm{~min}$ in the dark at ambient temperature. The reduction of the DPPH free radical was measured by reading the absorbance at $517 \mathrm{~nm}$. Methanol was used as control.

The percentage of inhibition was calculated from the absorbance of the control $\left(A_{\mathrm{c}}\right)$ and the sample $\left(A_{\mathrm{s}}\right)$ using the following equation: Inhibition $(\%)=\left[\left(A_{\mathrm{c}}-A_{\mathrm{s}}\right) / A_{\mathrm{c}}\right] \times 100$

\section{Results and discussion}

\section{Essential oil yield and chemical composition}

The essential oil yield of Juniperus leaves was found in variable amounts in all investigated species, ranging from $0.50-1.38 \%, 0.16-3.30 \%$ and $0.75-0.90 \% \mathrm{dw}$ for JF, JE and JC, respectively (Table 1). GC/FID/MS analysis showed presence of four main classes of components in all investigated samples of oils: monoterpene hydrocarbons $(\mathrm{MH})$, oxygen-containing monoterpenes $(\mathrm{OM})$, sesquiterpene hydrocarbons $(\mathrm{SH})$ and oxygen-containing sesquiterpenes (OS). In some samples diterpenes (D) were also determined in very small amounts as well as some non-terpene components (NT) (Table 1). The monoterpene hydrocarbons were the most abundant fraction in all investigated oils ranging from $39.97 \%$ to $53.39 \%, 40.96 \%$ to $42.80 \%$ and $38.22 \%$ to $83.21 \%$, in the essential oils of JC, JE and $\mathrm{JF}$, respectively. The second dominated fraction was variable for different oils, thus for JC it was sesquiterpene hydrocarbons (12.27-28.64\%), while for other two species it was oxygen containing sesquiterpenes, presenting a broad range from $10.10 \%$ to $39.71 \%$ and from $0.67 \%$ to $25.28 \%$, for essential oil of JF and JE, respectively (Table 1).

The two main components in JC essential oil were $\alpha$-pinene (21.27-28.68\%) and sabinene (2.29-16.27\%). Additionally, limonene was presented up to $6.95 \%$ and terpinene-4-ol up to $12.16 \%$. The monoterpene $\alpha$-pinene was extremely high in some samples of JE and JF (up to $33.83 \%$ and up to $67.61 \%$, for JE and JF, respectively). Additionally, the percentage of limonene was high, ranging up to $6.14 \%$ and $27.11 \%$ in samples of JE and JF, respective- ly. Some samples of JE contained high percentage of transsabinyl acetate (up to $10.38 \%$ ). In the same time, these oils were the only one containing thujones (cis-thujone up to $26.20 \%$ and trans-thujone up to $12.86 \%$ ).

Concerning the presence of sesquiterpene components, obtained results could not be classified and generalized as deferent components were present in deferent oils in a very different amount, from traces to very high percentage. Interesting component was sesquiterpene cedrol, found in $\mathrm{JF}$ and $\mathrm{JE}$ from $9.60-33.90 \%$ and from $0.0-24.44 \%$, respectively, while in JC it was not detected (Table 1). Other often identified sesqiterpene components were: trans-(E)-caryophyllene $(0.22-3.305$ and $0.81-3.45 \%$, for $\mathrm{JF}$ and JC, respectively, not detected in JF), germacrene D (1.21-4.16\% and $1.43-3.23 \%$ in JE and JC, respectively and only $0.2-0.5 \%$ in JF), $\delta$-cadinene $(0.2-1.5 \%, 0.31$ $3.95 \%$ and $2.05-7.98 \%$ for JF, JE and JC, respectively), $\alpha$-cadinol (up to $2.1 \%, 1.31 \%$ and $6.05 \%$ for JF, JE and JC, respectively). For JC oils, $\gamma$-cadinene and epi- $\alpha$-muurolol were characteristic, presented up to $2.26 \%$ and $4.13 \%$, respectively.

In general, considering the maximum determined percentages of the constituents of the oils, JF oil was characterized by three main components ( $\alpha$-pinene, limonene and cedrol, presented up to $67.63 \%, 27.11 \%$ and $33.91 \%$, respectively), JE oil by four components ( $\alpha$-pinene, sabinene, cis-thujone and cedrol, presented up to $33.83 \%$, $29.49 \%, 26.20 \%$ and $24.44 \%$, respectively) and JC oil by three components $(\alpha-$ pinene, sabinene and terpinen-4-ol, presented up to $28.68 \%, 16.27 \%$ and $12.16 \%$, respectively).

Compared to literature data, similarity in the composition of the leave essential oil was found with the Greek $J$. communis where $\alpha$-pinene (41.25\%) and sabinene (17.4\%) have been found as predominant constituents followed by smaller amounts of limonene (4.2\%), terpinen-4-ol (2.7\%), $\beta$-myrcene (2.6\%) and $\beta$-pinene (2.0\%) (Chatzopoulou and Katsiotis, 1993). Estonian J. communis leave oil was rich in $\alpha$-pinene (33.3-45.6\%) and sabinene (0.2-15.4\%) while limonene, trans-(E)-caryophyllene, $\alpha$-humulene and germacrene D were presented in smaller amounts (Orav et al., 2010a, 2010b). Filipowicz et al. (2009) have reported that populations of $J$. communis from Northern Poland have essential oils with different $\alpha$-pinene/sabinene ratio. Iranian authors reported that juniper leaves essential oil was rich in sabinene $(40.7 \%)$, followed by $\alpha$-pinene $(12.5 \%)$ and terpinen-4-ol (12.3\%) (Shahmir et al., 2003). Asili et al. (2008), confirmed $\alpha$-pinene as predominant component in the Iranian J. communis subsp. hemisphaerica LEO, while Ottavioli et al. (2009) for French J. communis subsp. alpina reported limonene (9.2-53.9\%), $\beta$-phellandrene (3.7$25.2 \%), \alpha$-pinene $(1.4-33.7 \%)$ and sabinene $(0.1-33.6 \%)$ as major constituents. The leave essential oil from Indian $J$. communis contained predominantly sabinene $(22.8 \%), \beta-$ pinene $(10.7 \%)$, trans-sabinene hydrate $(6.0 \%)$ and $\gamma$-cadinene (10.6\%) (Kumar et al., 2007).

Considering leaves essential oils of $J$. excelsa, many authors reported higher amounts of $\alpha$-pinene and cedrol. In 
Table 1. Essential oil yields (\%) and chemical composition of leaves essential oils of Juniperus foetidissima (JF), Juniperus excelsa (JE) and Juniperus communis (JC) from R. Macedonia (\%)

\begin{tabular}{|c|c|c|c|c|c|c|c|c|}
\hline Components & RI & RIE & $\begin{array}{c}\mathrm{JF} \\
\mathrm{min}\end{array}$ & $\begin{array}{c}\mathrm{JF} \\
\max \end{array}$ & $\begin{array}{c}\mathrm{JE} \\
\mathrm{min}\end{array}$ & $\begin{array}{c}\mathrm{JE} \\
\max \end{array}$ & $\begin{array}{c}\mathrm{JC} \\
\mathrm{min}\end{array}$ & $\begin{array}{c}\mathrm{JC} \\
\max \end{array}$ \\
\hline Tricyclene & 921 & 930.4 & $\operatorname{tr}$ & 0.12 & - & - & - & 0.04 \\
\hline$\alpha$-Thujene & 931 & 933.8 & - & - & 0.84 & 1.42 & - & 2.43 \\
\hline$\alpha$-Pinene & 932 & 937.2 & 9.62 & 67.63 & 1.76 & 33.83 & 21.27 & 28.68 \\
\hline Camphene & 946 & 945.5 & 0.21 & 1.01 & - & 0.47 & - & 0.91 \\
\hline Sabinene & 969 & 962.8 & - & - & 0.34 & 29.49 & 2.29 & 16.27 \\
\hline$\beta$-Pinene & 974 & 964.1 & 0.21 & 1.42 & - & - & - & 2.28 \\
\hline$\beta$-Myrcene & 988 & 976.4 & 0.62 & 1.94 & 0.46 & 2.78 & 0.55 & 2.12 \\
\hline$\Delta^{3}$-Carene & 1008 & 989.8 & 0.41 & 3.42 & - & - & - & 3.15 \\
\hline$\alpha$-Terpinene & 1018 & 998.3 & - & - & - & 1.87 & - & 0.12 \\
\hline$p$-Cymene & 1020 & 1001.8 & 0.21 & 0.32 & 0.19 & 0.88 & $\operatorname{tr}$ & 5.78 \\
\hline Limonene & 1024 & 1006.7 & 10.0 & 27.11 & 1.75 & 6.14 & - & 6.95 \\
\hline$\gamma$-Terpinene & 1054 & 1033.4 & 0.12 & 0.53 & $\operatorname{tr}$ & 3.53 & - & 0.23 \\
\hline$\alpha$-Terpinolene & 1086 & 1062.5 & 0.33 & 0.73 & - & 1.02 & - & 0.21 \\
\hline cis-Thujone & 1101 & 1079.2 & - & - & - & 26.20 & - & - \\
\hline trans-Thujone & 1112 & 1090.9 & - & - & - & 12.86 & - & - \\
\hline trans-Pinocarveol & 1135 & 1117.1 & - & - & - & - & - & 0.47 \\
\hline trans-Sabinol & 1140 & 1120.3 & - & - & - & 1.74 & - & 1.16 \\
\hline Camphor & 1141 & 1123.7 & 0.12 & 0.22 & - & - & - & - \\
\hline Borneol & 1165 & 1150.0 & $\operatorname{tr}$ & 0.12 & - & - & - & 0.28 \\
\hline Terpinen-4-ol & 1174 & 1161.8 & - & 0.11 & - & 5.87 & 0.55 & 12.16 \\
\hline p-Cymene-8-ol & 1179 & 1171.1 & - & 0.31 & - & - & - & 0.24 \\
\hline$\alpha$-Terpineol & 1186 & 1175.1 & - & $\operatorname{tr}$ & - & - & - & 0.37 \\
\hline Bornyl acetete & 1284 & 1263.4 & - & 0.11 & - & - & - & 0.78 \\
\hline trans-Sabinyl acetate & 1289 & 1268.5 & - & - & - & 10.38 & - & 0.13 \\
\hline$\delta$-Elemene & 1335 & 1306.0 & - & 0.32 & - & 0.12 & - & 0.14 \\
\hline$\alpha$-Cubebene & 1345 & 1318.6 & - & 0.21 & $\operatorname{tr}$ & 0.17 & - & 0.12 \\
\hline$\alpha$-Copaene & 1374 & 1345.4 & $\operatorname{tr}$ & 0.21 & 0.05 & 0.28 & - & 0.67 \\
\hline$\beta$-Bourbonene & 1387 & 1354.5 & - & 0.11 & 0.06 & 0.25 & - & 0.32 \\
\hline$\beta$-Elemene & 1389 & 1362.2 & - & - & - & - & 1.37 & 4.17 \\
\hline Sibirene & 1400 & 1380.1 & - & - & - & - & 0.31 & 2.31 \\
\hline$\beta$-Funebrene & 1413 & 1381.3 & - & 4.32 & - & - & - & - \\
\hline trans-Caryophyllene & 1418 & 1386.9 & $\operatorname{tr}$ & $\operatorname{tr}$ & 0.22 & 3.30 & 0.81 & 3.45 \\
\hline$\beta$-Cedrene & 1419 & 1387.7 & 0.54 & 2.72 & - & - & - & - \\
\hline$\beta$-Copaene & 1430 & 1396.1 & - & - & 0.05 & 1.19 & - & 0.20 \\
\hline$\gamma$-Elemene & 1434 & 1399.7 & - & - & - & 2.17 & 0.58 & 2.95 \\
\hline$\alpha$-Humulene & 1452 & 1421.8 & $\operatorname{tr}$ & 0.24 & $\operatorname{tr}$ & 0.45 & 0.07 & 2.89 \\
\hline$\gamma$-Muurolene & 1478 & 1444.6 & - & 0.24 & 0.06 & 0.92 & - & - \\
\hline Germacrene D & 1484 & 1449.9 & 0.27 & 0.54 & 1.21 & 4.16 & 1.43 & 3.23 \\
\hline$\beta$-Selinene & 1489 & 1455.1 & - & - & - & - & 0.11 & 0.64 \\
\hline$\alpha$-Selinene & 1498 & 1463.2 & - & - & - & - & 0.71 & 1.07 \\
\hline
\end{tabular}




\begin{tabular}{|c|c|c|c|c|c|c|c|c|}
\hline Components & RI & RIE & $\begin{array}{c}\mathrm{JF} \\
\min \end{array}$ & $\begin{array}{c}\mathrm{JF} \\
\max \end{array}$ & $\begin{array}{l}\mathrm{JE} \\
\min \end{array}$ & $\begin{array}{c}\mathrm{JE} \\
\max \end{array}$ & $\begin{array}{l}\mathrm{JC} \\
\mathrm{min}\end{array}$ & $\begin{array}{c}\mathrm{JC} \\
\max \end{array}$ \\
\hline$\alpha$-Muurolene & 1500 & 1468.3 & - & - & 0.21 & 1.83 & 0.45 & 1.32 \\
\hline$\gamma$-Cadinene & 1513 & 1482.1 & - & - & 0.11 & 1.92 & 0.60 & 2.26 \\
\hline$\delta$-Cadinene & 1522 & 1490.3 & 0.21 & 1.51 & 0.31 & 3.95 & 2.05 & 7.98 \\
\hline trans-Cadina-1,4-diene & 1533 & 1538.8 & - & 0.52 & - & 0.51 & - & 0.31 \\
\hline$\alpha$-Cadinene & 1537 & 1504.1 & - & - & - & 0.17 & - & 0.50 \\
\hline Germacrene B & 1559 & 1525.6 & - & - & - & 1.91 & - & 0.49 \\
\hline Spatulenol & 1577 & 1546.0 & - & - & - & - & - & 1.67 \\
\hline Caryophyllene oxide & 1581 & 1552.6 & 0.11 & 0.42 & - & - & - & 1.73 \\
\hline Cedrol & 1600 & 1576.2 & 9.62 & 33.91 & - & 24.44 & - & - \\
\hline Humulene epoxide II & 1608 & 1578.2 & - & - & - & - & 0.71 & 1.17 \\
\hline 1,10-di-epi-Cubenol & 1618 & 1582.8 & - & - & - & 0.08 & - & $\operatorname{tr}$ \\
\hline 1-epi-Cubenol & 1627 & 1595.2 & 0.12 & 0.82 & 0.05 & 0.93 & 0.39 & 2.31 \\
\hline epi- $\alpha$-Muurolol & 1640 & 1609.7 & - & 0.21 & - & - & 1.07 & 4.13 \\
\hline$\alpha$-Muurolol & 1645 & 1613.4 & - & 0.41 & - & 0.02 & - & 0.44 \\
\hline$\alpha$-Cadinol & 1653 & 1621.9 & - & 2.11 & - & 1.31 & 1.67 & 6.05 \\
\hline Manool oxide & 1987 & 1962.4 & - & 0.12 & - & - & - & 0.27 \\
\hline Abietatriene & 2054 & 2024.7 & - & $\operatorname{tr}$ & $\operatorname{tr}$ & 0.08 & - & 0.62 \\
\hline Abietadiene & 2080 & 2051.9 & $\operatorname{tr}$ & 0.12 & $\operatorname{tr}$ & 0.47 & - & 0.12 \\
\hline 4-epi-Abietal & 2298 & 2264.5 & - & 0.13 & $\operatorname{tr}$ & 0.21 & - & 0.04 \\
\hline \multicolumn{3}{|c|}{ Total (\%) } & 93.23 & 96.55 & 82.69 & 95.61 & 86.07 & 96.31 \\
\hline \multicolumn{3}{|c|}{ Monoterpene hydrocarbons (MH) } & 38.27 & 83.25 & 40.96 & 42.80 & 39.97 & 53.39 \\
\hline \multicolumn{3}{|c|}{ Oxygen containing monoterpenes (OM) } & 0.55 & 1.75 & 0.34 & 44.97 & 3.89 & 12.16 \\
\hline \multicolumn{3}{|c|}{ Sesquiterpene hydrocarbons (SH) } & 2.32 & 15.45 & 6.91 & 16.11 & 12.27 & 28.64 \\
\hline \multicolumn{3}{|c|}{ Oxygen containing sesquiterpenes (OS) } & 10.15 & 37.94 & 0.67 & 25.28 & 5.98 & 13.57 \\
\hline \multicolumn{3}{|c|}{ Diterpenes (D) } & $\operatorname{tr}$ & 0.37 & $\operatorname{tr}$ & 0.76 & - & 1.05 \\
\hline \multicolumn{3}{|c|}{ Non-terpene components (NT) } & 0.3 & 0.12 & - & - & - & 0.04 \\
\hline \multicolumn{3}{|c|}{ Essential oil yield $(\%, \mathrm{dw})$} & 0.50 & 1.38 & 0.16 & 3.30 & 0.75 & 0.90 \\
\hline
\end{tabular}

RI - Retention index - literature data (Adams, 2007); RIE - Retention index experimentally determined with reference to a homologous series of $n$-alkanes on HP-5ms column (AMDIS); (-) - not found, tr - traces $<0.02$

some earlier papers Adams reported that the oil from wild growing $J$. excelsa from Greece contained cedrol (28.1\%), $\alpha$-pinene $(22.5 \%)$ and limonene $(22.7 \%)$ as predominant constituents (Adams, 1990). Also, Turkish authors found $\alpha$-pinene (29.7\%) and cedrol (25.3\%) (Topcu et al., 2005) as dominant for this species. Moreover, Iranian researchers confirmed these two components as predominant in the leaf essential oil from wild growing $J$. excelsa from Iran ( $\alpha$-pinene $32.34 \%$ and cedrol $13.06 \%$ ) (Emami et al., 2011a). Recently, Adams et al., revealed presence of mod- erate geographical variations in the volatile leaves oil of $J$. excelsa, comparing the samples from Greece, Bulgaria, Turkey and Cyprus (Adams et al., 2013) where cedrol was found to be the most abundant constituent of the oils, ranging from 11.3 to $35.8 \%$. These data are in correlation with our findings for some samples of $J$. excelsa, but some other samples from Republic of Macedonia possess essential oil with deferent oil composition characterized with larger percentages of sabinene and thujone (cis + trans) $(29.49 \%$ and $39.06 \%$, respectively). 
According to literature data leaf essential oil of $J$. foetidissima was characterized by monterpene hydrocarbons as predominated constituents of the oil. For the leaves essential oil of J. foetidissima from Greece, Adams reported sabinene (19.6\%), $\alpha$-thujone (18.6\%), terpinen-4-ol (17.6\%) and $\gamma$-terpinene $(6.5 \%)$ as major components (Adams, $1990 \mathrm{~b})$. At the same time, the minor compounds of this essential oil were $\alpha$-terpinene (4.3\%), $\beta$-thujone (3.5\%), cedrol (3.2\%), myrcene $(2.7 \%)$ and $\alpha$-pinene $(2.6 \%)$. Iranian researchers found that the major components of the essential oils of fruits, leaves of male and leaves of female plant of $J$. foetidissima were sabinene (37.1, 19.9 and 16.8\%), $\alpha$-pinene (29.9, 22.2 and 18.6\%) and limonene (11.8, 20.9 and $13.6 \%$ ), respectively (Asili et al., 2010). Considering essential oil composition of $J$. foetidissima from Balkans, only one article was published by Lesjak et al. (2013) who reported sabinene $(39.9 \%), \gamma$-terpinene $(10.1 \%)$ and terpinen-4-ol (17.0\%) as major monoterpenes and germacrene D $(0.7 \%)$ and $\gamma$-cadinene $(2.9 \%)$ as major sesquiterpene. Our findings showed higher percentage of $\alpha$-pinene $(67.63 \%)$, followed by larger amounts of cedrol (up to $33.91 \%$ ) and limonene (27.11\%).

\section{The contents of total phenols and total flavonoids and $D P P H$ radical scavenging activity}

The obtained values for total phenols content determined with the Folin-Ciocalteu reagent (TPC-FC) as well as total flavonoid content determined spectrophotometrycally using $\mathrm{AlCl}_{3}$ as chelating agent (TFC-AlCl$)$ are presented in Table 2. In all investigated samples of Juniperus leaves the content of TPC-FC was almost twice higher in water extracts (96.18-122.91 mg GAE/g dw) compared to ethanol extracts (47.72-64.42 $\mathrm{mg} \mathrm{GAE} / \mathrm{g} \mathrm{dw})$. On the contrary, the contents of TFC-AlCl 3 were slightly higher in ethanol extracts (2.05-11.91 mg CE/g dw) compared to water extracts (1.95-10.25 mg CE/g dw). Leaves extract of JF and JE, both water and ethanol contained much higher content of TFC-AlCl $\mathrm{Al}_{3}$ than JC extracts.

Leaves extracts of investigated Juniperus species (JF, JE and JC), both water and ethanol extracts, showed radical scavenging capacity expressed as $\%$ of inhibition of the DPPH radical that had broad range depending on the extract concentration. In both cases more concentrated extracts have shown better results and water extracts have demonstrated stronger scavenging activity (Table 3). Thus, the highest radical scavenging activity against DPPH radi-

Table 2. The content of total phenols (TPC - FC, mg GAE/g dw) and total flavonoids (TFC - $\mathrm{AlCl}_{3}$, mg CE/g dw) in leaves of Juniperus foetidissima (JF), Juniperus excelsa (JE) and Juniperus communis (JC)

\begin{tabular}{ccccc}
\hline \hline Specimen & $\begin{array}{c}\text { TPC-FC } \\
\text { water extract }\end{array}$ & $\begin{array}{c}\text { TPC-FC } \\
\text { ethanol extract }\end{array}$ & $\begin{array}{c}\text { TFC-FC } \\
\text { water extract }\end{array}$ & $\begin{array}{c}\text { TFC-AlCl } \\
\text { ethanol extract }\end{array}$ \\
\hline JF & $118.87 \pm 0.68$ & $60.45 \pm 1.62$ & $10.25 \pm 1.16$ & $11.91 \pm 1.24$ \\
JE & $122.91 \pm 0.35$ & $64.42 \pm 1.34$ & $8.85 \pm 0.94$ & $8.92 \pm 1.84$ \\
JC & $96.18 \pm 1.22$ & $47.72 \pm 0.86$ & $1.95 \pm 0.04$ & $2.05 \pm 0.52$ \\
\hline
\end{tabular}

Table 3. Radical scavenging activity against DPPH radical expressed as \% of inhibition for leaves extracts of Juniperus foetidissima (JF), Juniperus excelsa (JE) and Juniperus communis (JC)

\begin{tabular}{cccc}
\hline Sample & \multicolumn{3}{c}{ \% of inhibition of DPPH radical } \\
& JF & JE & JC \\
\hline Ethanol extracts $(\mathrm{mg} / \mathrm{ml})$ & $18.32-20.12$ & $48.73-48.82$ & $74.4-76.7$ \\
100 & $17.25-18.36$ & $39.32-42.12$ & $55.7-70.7$ \\
50 & $5.61-6.64$ & $33.03-34.32$ & $27.3-42.8$ \\
20 & 0.0 & $14.42-16.24$ & $11.2-23.1$ \\
10 & & & \\
Water extracts $(\mathrm{mg} / \mathrm{ml})$ & $60.56-64.52$ & $59.74-67.4$ & $60.56-78.23$ \\
10 & $45.40-48.25$ & $40.72-72.6$ & $41.95-45.40$ \\
5 & $18.23-20.19$ & $15.04-43.4$ & $19.86-20.19$ \\
2 & $10.42-12.32$ & $8.54-25.71$ & $11.19-12.31$ \\
\hline
\end{tabular}

Макед. фарм. билт., 60 (2) 29 - 37 (2014) 
cal showed water extract of JF, JE and JC leaves in concentration $10 \mathrm{mg} / \mathrm{ml}$, with \% of inhibition of DPPH ranging up to $64.52 \%, 67.40 \%$ and $78.23 \%$, respectively.

Tavares et al. (2009) evaluated the possibility of application of Juniperus leaves from species naturally occurring in Portugal (J. phoenicea subsp. phoenicea, J. turbinata, J. oxycedrus subsp. oxycedrus, J. oxycedrus subsp. badia and $J$. navicularis) against some diseases in which oxidative reactions play a crucial role. They found that all species exhibited minimum polyphenol and flavonoid contents in March/April and July and therefore a reduced antioxidant activity while the maximum concentrations of these compounds were detected in November/December, when they demonstrated higher antioxidant capacity (Taveras et al., 2009).

The antioxidant activity of leaves and fruits of 11 different conifer taxons growing wild in Iran were evaluated by Emami et al. (2007). Methanol extract of leaves and fruits were prepared and antioxidant activity of each extracts was measured using two different tests (the ferric thiocyanate method and thiobarbituric acid test, TBA). Results indicated that the methanol extracts of leaves, of male and female, and fruits of all these species possessed antioxidant activity when tested with both methods. The antioxidant capacity was then compared with those of $\alpha$-tocopherol (a natural antioxidant) and butylated hydroxytoluene (BHT, a synthetic antioxidant). Methanol extract of Juniperus species, especially J. excelsa, J. excelsa ssp. polycarpos, J. oblonga and J. foetidisima, demonstrated antioxidant activity comparable to the BHT and even higher than $\alpha$-tocopherol (Emami et al., 2007).

A correlation was found between the primary antioxidant activity and the total phenolic contents in different $J u$ niperus species (J. communis var. communis (Jcc), J. communis var. saxatilis Pall. (Jcs), J. drupacea Labill. (Jd), J. oxycedrus subsp. oxycedrus (Joo) and J. oxycedrus subsp. macrocarpa (Sibth. \& Sm.) Ball. (Jom)) from Turkey by Taviano et al. (2011). Both in DPPH and TBA test, Jom resulted the most active $\left(\mathrm{IC}_{50}=0.034 \pm 0.002 \mathrm{mg} / \mathrm{ml}\right.$ and $0.287 \pm 0.166 \mu \mathrm{g} / \mathrm{ml}$, respectively). Different extracts of leaves, ripe fruits, and unripe fruits of Juniperus species, including $J$. communis, were studied for antioxidant activity by the ferrous ion-chelating, superoxide radical scavenging and ferric-reducing antioxidant power (FRAP) assays. It was found that all investigated Juniperus samples possessed antioxidant activity, but the leaves extracts usually had higher antioxidant activity (Orhan et al., 2011).

\section{Conclusion}

Chemical characterization of three Juniperus species, $J$. foetidisima (JF), J. excelsa (JE) and J. communis (JC) from Macedonian flora enclosed determination of yield and essential oil composition of the oils obtained by hydrodistillation of dried leaves and determination of the content of total phenols and total flavonoids in dried plant ma- terial. With GC/FID/MS analysis the essential oil profile of all investigated species was characterized dominantly with monoterpene hydrocarbon fraction. Sesquiterpene cedrol was found as an important constituent of the JF and JE oils, however the essential oil from JF was additionally characterized by two other main components ( $\alpha$-pinene and limonene), while the JE oil by three components ( $\alpha$-pinene, sabinene and cis-thujone). The essential oil of JC was free of cedrol, despite the fact that the fraction of sesquiterpene components of this oil was relatively high, but it consisted of many components presented in lower percentages and this oil was characterized mainly by three monoterpene components ( $\alpha$-pinene, sabinene and terpinen-4-ol).

The content of total phenols determined by Folin-Ciocalteu method ranged from 96.18-122.91 mg GAE/g dw (water extraction) while the content of total flavonoids ranged from 2.05-11.91 $\mathrm{mg} \mathrm{CE} / \mathrm{g} \mathrm{dw}$ (ethanol extraction). Both water and ethanol extracts possessed radical scavenging activity against DPPH radical but water extract were more powerful with \% of inhibition of DPPH ranging up to $64.52 \%, 67.40 \%$ and $78.23 \%$ for water extract $(10 \mathrm{mg} /$ $\mathrm{ml}$ ) of JF, JE and JC, respectively. Obtained results showed correlation with the content of total phenols as the water extracts contained higher amounts of total phenols and exhibited better antioxidant activity.

The leaves of Juniperus species from Macedonian flora (J. foetidisima, J. excelsa and J. communis) can be taken in further consideration as a plant source for isolation of essential oil as well for extraction of phenolic compounds with promising antioxidant activity. Further research is needed to evaluate the chemical and biological potential of this raw plant material.

\section{References}

Adams, R. 1987. Investigation of Juniperus Species of the United States for New Sources of Cedarwood Oil I. Economic Botany 41, 48-54.

Adams, R.P. 1990a. The chemical composition of leaf oils of Juniperus excelsa M. Bieb. J. Essent. Oil Res. 2, 45-8.

Adams, R. 1990b. Variation in the chemical composition of the leaf oil of Juniperus foetidissima Willd. J. Essent. Oil Res. 2, 67-70.

Adams, R., 2007. Identification of essential oil components by gas chromatography/mass spectrometry. 4th Ed. Illinois: Allured Publishing Corporation IL, USA, pp 9-31.

Adams, R.P., Tashev, A.N., Baser, K.H.K., Christou, A.K. 2013. Geographic variation in volatile leaf oils of Juniperus excelsa M. Bieb. Phytologia 95(4), 279-285.

Angioni, A., Barra, A., Russo, M.T., Coroneo, V., Dessi, S., Cabras, P., 2003. Chemical composition of the essential oils of Juniperus from ripe and unripe berries and leaves and their antimicrobial activity. J. Agric. Food Chem. 51 (10), 3073-3078

Asili, J., Emami, S.A., Rahimizadeh, M., Fazly-Bazzaz, B.S., Hassanzadeh, M.K. 2008. Chemical and Antimicrobial Studies of Juniperus excelsa subsp. excelsa and Juniperus excelsa subsp. polycarpos essential oils. J. Essent. Oil Bear. 
Pl. 11(3), 292-302.

Asili, J., Emami, S.A., Rahimizadeh, M., Fazly-Bazzaz, B.S., Hassanzadeh, M.K. 2010. Chemical and antimicrobial studies of Juniperus sabina L. and Juniperus foetidissima Willd. essential oils. J. Essent. Oil Bear. P1. 13, 25-36.

Atas, A.D., Goze, I., Alim, A., Cetinus, S.A., Durmus, N., Vural, N., Cakmak, O. 2012. Chemical Composition, Antioxidant, Antimicrobial and Antispasmodic Activities of the Essential Oil of Juniperus excelsa subsp. excelsa. J. Essent. Oil Bear. Pl. 15(3), 476-483.

Balaban, M., Atik, C., Ucar, G. 2003. Fungal growth inhibition by wood extracts from Juniperus foetidissima and J. oxycedrus. Holz als Roh und Werkstoff 61, 231-232.

Chaouche, T.M., Haddouchi, F., Ksouri, R., Medini, F., AtikBekara, F. 2013. In vitro evaluation of antioxidant activity of the hydro-methanolic extracts of Juniperus oxycedrus subsp. oxycedrus, Phytothérapie 11 (4), 244-249.

Chatzopoulou, P.S., Katsiotis, S.T., 1993. Chemical investigation of the leaf oil of Juniperus communis L. J. Essent. Oil Res. 5 (6), 603-607.

Ehsani, E., Akbari, K., Teimouri, M., Khadem, A. 2012. Chemical composition and antibacterial activity of two Juniperus species essential oils. Afr J Microbiol Res. 6(38), 6704-10.

Emami, S.A., Abedindo, B.F., Hassanzadeh-Khayyat, M. $2011 \mathrm{a}$. Antioxidant Activity of the Essential Oils of Different Parts of Juniperus excelsa M. Bieb. subsp. excelsa and $J$. excelsa M. Bieb. subsp. polycarpos (K. Koch) Takhtajan (Cupressaceae). Iran J Pharm Res. 10(4), 799-810.

Emami, S.A., Asgary, S., Naderi, G.A., Shams Ardekani, M.R., Kasher, T., Aslani, S., Airin, A., Sahebkar, A. 2011b. Antioxidant activities of Juniperus foetidissima essential oils against several oxidative systems. Revista Brasileira de Farmacognosia 21, 627-634.

Emami, S.A., Asili, J., Mohagheghi, Z., Hassanzadeh, M.K. 2007. Antioxidant Activity of Leaves and Fruits of Iranian Conifers. Evidence Based Complementary and Alternative Medicine 4, 313-319.

Filipowicz, N., Madanecki, P., Gołębiowski, M., Stepnowski, P., Ochocka, R.J., 2009. HS-SPME/GC analysis reveals the population variability of terpene contents in Juniperus communis needles. Chem. Biodiv. 6(12), 2290-2301.

Gyamfi, MA, Yonamine M, Aniya Y. 1999. Free-radical scavenging action of medicinal herbs from Ghana Thonningia sanguinea on experimentally-induced liver injuries. Gen Pharmacol. 32, 661-667.

Khan, M., Khan, A., Rehman, N., Gilani, A.H. 2012. Pharmacological explanation for the medicinal use of Juniperus excelsa in hepatoprotective gastrointestinal and respiratory disorders. J. Nat. Med. 66, 292-301.

Koukos, P.K., Papadopoulou, K.I., 1997. Essential oil of Juniperus communis L. grown in northern Greece: variations of fruit oil yield and composition. J. Essent. Oil Res. 9 (1), 35-39.

Kumar, A., Yadav, L.B.S., Ahmad, J., Dubey, N., Puri, S., 2007. Chemical composition of commercial Juniperus communis L. leaf oil. J. Essent. Oil Bear. Pl. 10 (4), 310-313.

Lesjak, M.M., Beara, I.N., Orcic, D.Z., Ristic, J.D., Anackov, G.T., Bozin, B.N., Mimica-Dukic, N.M. (2013) Chemical characterisation and biological effects of Juniperus foetidissima Willd. 1806. Food Science \& Technology 53, 530-539.

Marcysiak, K., Mazur, M., Romo, A., Montserrat, J.M., Didikuh, Y., Baratynska, K., Jasinski, A., Kosinski, P., Boratynski,
A. (2007) Numerical taxonomy of Juniperus thurifera, Juniperus excelsa and Juniperus foetidissima (Cupressaceae) based on morphological characters. Botanical Journal of the Linnean Society 155, 483-495.

Micevski, K., 1998. Flora na R. Makedonija. 1st Ed. Skopje: Makedonska Akademija na Naukite i Umetnostite (MANU), Skopje, pp. 81-84.

Modnicki, D., Łabędzka, J. 2009. Estimation of the total phenolic compounds in juniper sprouts (Juniperus communis L., Cupressaceae) from different places at the kujawskopomorskie province, Herba Polonica 55 (3), 127-132.

Moein, M.R., Ghasemi, Y., Moein, S., Nejati, M. 2010. Analysis of antimicrobial, antifungal and antioxidant activities of Juniperus excelsa M. B. subsp. polycarpos (K. Koch) Taghtajan essential oil. Pharmacog. Res. 2(3), 128-31.

Moein, M.R., Moein, S., Mousavi, F. 2014. Study on relationship between antioxidant potential and phenolic contents of Juniperus excelsa fruit, International Journal of Pharmacy and Pharmaceutical Science 6(7), 192-194.

Orav, A., Kailas, T., Müürisepp, M., 2010a. Chemical investigation of the essential oil from berries and needles of common juniper (Juniperus communis L.) growing wild in Estonia. Nat. Prod. Res. 24 (19), 1789-1799b.

Orav, A., Koel, M., Kailas, T., Müürisepp, M., 2010b. Comparative analysis of the composition of essential oils and supercritical carbon dioxide extracts from the berries and needles of Estonian juniper (Juniperus communis L.). Procedia Chem. 2, 161-167.

Orhan, N., Akkol, E., Ergun, F. 2012. Evaluation of antiinflammatory and antinociceptive effects of some Juniperus species growing in Turkey. Turkish Journal of Biology 36, 719-726.

Orhan, N., Orhan, I. E., \& Ergun, F. 2011. Insights into cholinesterase inhibitory and antioxidant activities of five Juniperus species. Food and Chemical Toxicology 49(9), 2305-2312.

Ottavioli, J., Gonny, M., Casanova, J., Bighelli, A., 2009. Chemical variability of the needle oil of Juniperus communis ssp. alpina from Corsica. Chem. Biodivers. 6 (12), 21922199.

Ozturk, M., Tumen, I., Ug'ur, S., Aydog, F., Topcu, G. 2010. Evaluation of fruit extractas of six Turkish Juniperus species for their antioxidant, anticholinesterase and antimicrobial activities. Journal of the Science of Food and Agriculture 91, 867-876.

Sadaeghi-Aliabadi, H., Emami, A., Saidi, M., Sadeghi, B., Jafarain, A. 2009. Evaluation of in vitro cytotoxic effects of Juniperus foetidissima and Juniperus sabina extracts against a panel of cancer cells. Iranian Journal of Pharmaceutical Research 8, 281-286.

Shahmir, F., Ahmadi, L., Mirza, M., Korori, S.A.A., 2003. Secretory elements of needles and berries of Juniperus communis L. ssp. communis and its volatile constituents. Flavour Frag. J. 18 (5), 425-428.

Singleton, V.L., Orthofer, R., Lamuela-Raventos, R.M. 1999. Analysis of total phenols and other oxidation substrates and antioxidants by means of Folin-Ciocalteu reagent. Methods Enzymol. 299,152-178.

Talari, S., Rudroju, S., Penchala, S., Nanna Rama, S. 2012. Quantification of total phenolic and total flavonoid contents in extracts of Oroxylum indicum L. Kurz, Asian J. Pharm. Clin. Res. 5(4), 177-179.

Tavares, L., Pimpao, R.C., Santos, C., McDougall, G.J., Stewart,

Макед. фарм. билт., 60 (2) 29 - 37 (2014) 
D., Ferreira, RB. 2009. Phytochemical characterization of Juniperus spp. leaves, Planta Med. 75 - PA73, DOI: 10.1055/ s-0029-1234398.

Taviano, M.F., Marino, A., Trovato, A., Bellinghieri, V., La Barbera, T.M., Guvenc, A., Hurkul, M.M., Pasquale, R., Miceli, N. 2011. Antioxidant and antimicrobial activities of branches extracts of five Juniperus species from Turkey. Pharm. Biol. 49, 1014-1022.

Tayoub, G., Odeh, A., Ghanem, I. 2012. Chemical composition and efficacy of essential oil from Juniperus foetidissima Willd against the Kharpa Beetle. International Journal of Medicinal and Aromatic Plants 2, 501-508.
Topçu, G., Gören, A.C., Bilsel, G., Bilsel, M., Çakmak, O., Schilling, J., Kingston, D.G.I. 2005. Cytotoxic Activity and Essential Oil Composition of Leaves and Berries of Juniperus excelsa. Pharmaceutical Biology 43(2), 125-8.

Tunalier, Z., Kirimer, N., Baser, K.H.C. 2002. The composition of essential oils from various parts of Juniperus foetidissima. Chemistry of Natural Compounds 38, 43-47.

Unlu, M., Vardar-Unlu, G., Vural, N., Domnez, E., Cakmak, O. 2008. Composition and antimicrobial activity of Juniperus excelsa essential oil. Chemistry of Natural Compounds 44 (1), 129-131.

\title{
Хемиска карактеризација и инхибиторна радикалска активност на листови од Juniperus foetidisima, J. excelsa и J. communis од Македонска флора
}

\author{
Марија Карапанџова ${ }^{1 *}$, Ѓ оше Стефков ${ }^{1}$, Ивана Цветковиќ $^{1}$, Фљореша Сеља ${ }^{1}$, \\ Татјана Кадифкова Пановска ${ }^{2}$, Светлана Кулеванова ${ }^{1}$
}

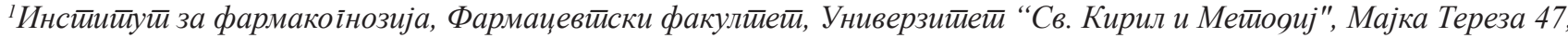 \\ 1000 Скойје, Рейублика Макеоонија

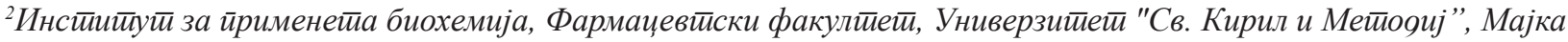 \\ Тереза 47, 1000 Скойје, Рейублика Макеоонија
}

Клучни зборови: Juniperus communis, Juniperus excelsa, Juniperus foetidosima,состав на етерично масло, GC/MS, вкупни феноли, вкупни флавоноиди, DPPH.

Хемиската карактеризација на три Juniperus вида, J. foetidisima (JF), J. excelsa (JE) и J. communis (JC) од Македонската флора, вклучува определување на содржина и состав на етерични масла добиени со дестилација со водена пареа на суви листови, како и определување на содржина на вкупни феноли и вкупни флавоноиди во сувиот материјал. Co GC/FID/MS анализата утврден е монотерпенски профил на маслото од JC и монотерпенско/ сесквитерпенски профил на маслата од JF и JE. Сесквитерпенот цедрол е идентификуван како важен конституент на маслата од JF и JE, при што маслото од JF се карактеризира со три главни компоненти ( $\alpha-$ пинен, лимонен и цедрол, во количини што се движат до $67,63 \%, 27,11 \%$ и $33,91 \%$, соодветно), додека маслото од JЕ се карактеризира со четири главни компоненти ( $\alpha-$ пинен, сабинен, cis-тујон и цедрол, присутни во количини до $33,83 \%, 29,49 \%$, $26,20 \%$ и $24,44 \%$, соодветно). Маслото од ЈС не содржи цедрол, иако содржи релативно висок удел на сесквитерпени (сесквитерпенски јаглеводороди и сесквитерпени со кислорд во количини што се движат до 28,64\% и до 13,57\%, соодветно). Ова масло се карактеризира главно со три монотерпенски компоненти ( $\alpha-$-пинен, сабинен и терпинен-4ол, застапени до $28,68 \%$, до $16,27 \%$ и до $12,16 \%$, соодветно). Содржината на вкупните феноли определена со метод по Folin-Ciocalteu се движи од 96,18 до122,91 mg GAE/g (водена екстракција), а содржината на вкупни флавоноиди од 2,05 до 11,91 mg CE/g (етанолна екстракција). Двата екстракти (водениот и етанолниот) поседуваат инхибирачка активност во однос на DPPH радикалот. Водените екстракти се помоќни бидејќи во концентрација од $10 \mathrm{mg} / \mathrm{ml}$ покажуваат \% на инхибиција на DPPH радикалот кој се движи до 64.52\%, до 67.40\% и до 78.23\%, за JF, JE и JC, соодветно. Добиените резултати покажуваат корелација со содржината на вкупните феноли. 